\title{
An Experimental Design to Test the Main and Interaction Effects of CSR Involvement, Brand Naming, and Pricing on Purchase Intentions in Thailand
}

\author{
Apicha Boonpattarakan ${ }^{1}$ \\ ${ }^{1}$ School of Business Administration, Bangkok University, Bangkok, Thailand \\ Correspondence: Apicha Boonpattarakan, School of Business Administration, 119 Rama IV Road, Klongtoey, \\ Bangkok 10110, Thailand. Tel: 66-2350-3500 (ext. 1640).E-mail: apicha1961@yahoo.com
}

Received: May 6, 2012 Accepted: June 2, 2012 Online Published: August 16, 2012

doi:10.5539/ijbm.v7n16p62 URL: http://dx.doi.org/10.5539/ijbm.v7n16p62

\begin{abstract}
This study attempted to test the main and interaction effects of CSR involvement, brand naming, and pricing on consumers' purchase intentions by using a $2 \times 2 \times 2$ experimental design. CSR involvement was based on a cause-related marketing campaign. Brand naming was based on a local/Thai brand name and a foreign brand name signifying that the product is from a renowned country. High prices and low prices were adopted for the pricing factor. A computer notebook was used to represent a high involvement and technological product for the experiment. Siam Computer was used to represent a Thai brand name whereas Toshisu was used to represent a foreign brand name. Students from a local university were recruited as experimental subjects. Fifty subjects were randomly assigned to each of the eight experimental conditions. All three experimental factors were found to have significant effects on purchase intentions. The levels of purchase intentions were found to be higher for products with CSR involvement, foreign brand name, and lower prices. The two way interaction effects suggested that CSR involvement had a positive effect on products with foreign brand name and higher prices. The effect of pricing was found to be stronger for products using Thai brand name. The three way interaction effect suggested that for a high price condition, CSR involvement had a strong effect on purchase intentions for products using a foreign brand name whereas in a low price condition, CSR involvement had no significant effect regardless of the name of the brand.
\end{abstract}

Keywords: CSR, corporate social responsibility, cause-related marketing, brand naming, pricing, purchase intentions

\section{Introduction}

What is the purchase criteria consumers use for brand evaluation is a very good question in today's competitive environment. The typical purchase criteria consumers use for a high involvement and technological product, such as an air conditioner, an LCD or LED TV, an electrical washer, a computer notebook, a digital camera, etc., may include the name of the brand itself, brand image, brand reputation, product features, product design, product quality, product usefulness, ease of use, and prices (Davis, Bagozzi, \& Warshaw, 1989; McClary, 2006). However, the most influential factors in today's consumer decision making process are deemed to be based on the brand name itself, brand image, and prices. It is believed that for a high involvement and technological product, the name of the brand will generally convey the quality of the product. For example, HP and Toshiba are renowned for their computer notebooks (Ten Best Notebook, 2012). LG and GE are renowned for their washing machines (Top Three Best Reviews, 2012). The renowned air conditioner in Thailand is perceived to be Mitsubishi, Mr. Slim (Mitsubishi Electric, 2012). These examples imply that developed countries like Japan, USA, and South Korea are reputed for manufacturing technological products. However, even though past research has been carried out to examine the effects of product country image and country of origin, it still lacks a clear understanding of the differences between the use of a local brand name and a foreign brand name signifying that the product is owned by a company from a country that has an expertise in manufacturing that product. The concept of brand image also has an influential effect on consumer decision making process (Arslan \& Altuna, 2010; Keller, 1993; Lee, Lee, \& Wu, 2011). Brand image is commonly defined as "the perceptions about a brand as reflected by the brand associations held in consumer memory" (Keller, 1993, p.3). Even though the name of the brand itself may convey some aspects of image, such as quality image, value image, ease of use image, etc., 
associating a brand with a cause-related marketing campaign, a form of corporate social responsibility (CSR), will also likely to create a positive image toward the brand. Recently, the concept and the form of CSR have been widely examined and studied; however, its effect on consumers' purchase behavior is still not well understood. Will an involvement in a CSR campaign help increase the company's sales and revenue? This is a good question that current research in this area must try to address and clarify. In addition, another significant purchase criterion is the price of the product. Even though past research has investigated the concept of price sensitivity (Diamantopoulos, 2003; Goldsmith, Flynn, \& Kim, 2010), its concept is still poorly understood. The interaction effects among these three major purchase criteria concerning the name of the brand, brand image resulting from a CSR campaign, and the price of the product/brand are also not well understood. Hence, the objectives of this study were to test the main and interaction effects of CSR involvement, brand naming, and pricing of a technological product (i.e., a high involvement product) on consumers' purchase intentions. A 2 × 2 × 2 experimental design was carried out to examine the research objectives.

\section{Literature Review}

\subsection{Main Effects of CSR Involvement, Brand Naming, and Pricing}

\subsubsection{Corporate Social Responsibility}

The European Commission defines corporate social responsibility as "the responsibility of enterprises for their impacts on society" ("Corporate Social Responsibility: a new definition," 2012). It is a concept whereby companies integrate social and environmental concerns in their business and operations. It can be considered a form of corporate self-regulation integrated into business practices. It is often referred to as corporate social investment, corporate sustainability, corporate conscience, community relations, investor relations, social performance, sustainable responsible business, corporate philanthropy, societal marketing, social marketing, and others (Corporate Social Responsibility, 2012; Wood, 1991). The concept of corporate social responsibility has been adopted and carried out for quite sometime and has been increasingly seen as an imperative for building corporate sustainability. The common theme rests on the principle that business corporations are supposed to serve as good corporate citizens (Gardberg \& Fombrun, 2006; Windsor, 2001). Fundamentally, the concept of CSR is based on the stakeholder theory, a philosophy that drives corporations to do social works related to those individuals or groups that may be affected by corporate activities (Donaldson \& Preston, 1995; Phillips, 2003). This theory thus proposes that all corporations should have social responsibilities toward the society's well being. Early models of CSR appeared in the 1960s. The models included the social aspect of CSR that covered responsibility beyond economic and legal obligations (Carroll, 1979; Matten \& Crane, 2005; Meehan, Meehan, \& Richards, 2006). It is synonymous with voluntary and philanthropic activities designed to improve social welfare. CSR is therefore based on the concept that the corporations not only try to satisfy the needs of their customers and shareholders but also try to satisfy the needs of the social actors/stakeholders associated with corporations. It is deemed to be the corporation's responsibility to help improve the community and society's well-being (Chen, 2011; Galbreath, 2009; Moir, 2001).

Corporate social responsibility is analogous to the concept of socially responsible marketing described by Kotler and Keller (2006). Socially responsible marketing is one of the four dimensions of holistic marketing concept, consisting of relationship marketing, integrated marketing, internal marketing, and socially responsible marketing, proposed by Kotler and Keller (2006). It implies that marketing efforts should be extended to cover other stakeholders and society. It is important for corporations to help contribute to the social and community welfare. The concept of socially responsible marketing is therefore similar to the concept of corporate social responsibility. Kotler and Lee (2005) classify corporate social responsibility into six categories. These six categories include cause promotions, cause-related marketing, corporate social marketing, corporate philanthropy, community volunteering, and socially responsible business practices. According to Kotler and Lee (2005), cause promotions refer to the activities that support social causes through promotional sponsorships whereas cause-related marketing refers to the contribution or donation as a percentage of product sales or revenue to a specific charitable cause. Corporate social marketing refers to the contribution that supports behavioral change campaigns. Corporate philanthropy refers to direct contribution or donation made to a charity. Community volunteering refers to the volunteer services given to the society. Socially responsible business practices refer to the adoption of a discretionary business practice that supports social causes. In this research, the focus is on one aspect of CSR, i.e., cause-related marketing.

Cause-related marketing has recently been adopted as a strategic element. It has become an essential form of corporate giving. It leads corporations to "do well by doing good" by donating part of the revenue from selling the corporation's products or services to good causes or charitable organizations (Cause-Related Marketing, 
2012). The recent interest in cause-related marketing stemmed from the case of American Express who used the term "cause-related marketing" in 1983 to describe its campaign to raise money for the Statue of Liberty's restoration. Every time an American Express card holder used the card, a donation was made to the Statue of Liberty's restoration. In addition, an additional amount for every new American Express credit card customer was also donated to the same cause (Cause Marketing, 2012). Additional example includes the campaign that was carried out by those companies who intended to fight breast cancer by selling pink ribbon pins, teddy bears, and yoghurt, and donated part of the revenue to breast cancer research ("Cause-Related Marketing: Why Social Change," 2012). MAC, a company who produces premium cosmetics, donated every cent of the selling of MAC Viva Glam lipstick and lipglass to the MAC AIDs Fund (Top Eight Cause-Related Marketing Campaigns of 2007, 2011). In 1997, Yoplait Yogurt carried out a cause-related marketing campaign by donating ten cents for every cup of yogurt sold to the Susan G. Komen Breast Cancer Foundation (Berglind \& Nakata, 2005). Epson also donated a certain sum to CRY (a charitable organization) for every dot matrix printer sold during the month of August 2004 (Sundar, 2012). In Thailand, a number of business organizations have also carried out cause-related marketing campaigns. For example, Cerebos (Thailand) Ltd. who sold BRAND's essence of chicken and BRAND's bird's nest donated part of gift basket purchase to the Prostheses Foundation (Social News, 2012). Better Way (Thailand) Co., Ltd. (who distributes and sells Mistine cosmetics) donated 10 Baht for every diamonds lipstick purchased to the Foundation for the Blind in Thailand (Mistine, 2012).

Varadarajan and Menon (1988, pp. 60-61) define cause-related marketing as "the process of formulating and implementing marketing activities that are characterized by an offer from the firm to contribute a specified amount to a designated cause when customers engage in revenue providing exchanges." An involvement in a cause-related marketing campaign will help enhance business corporations' brand image and lead to a positive product evaluation by consumers. As a result, cause-related marketing has been adopted as a competitive strategy by many corporations around the world to build corporate image and brand image by linking product sales to the support of a charity. It is believed that an arrangement between a business organization and a charitable organization to raise money for a particular cause will help enhance both corporate image and brand image and, as a result, leading to an increase in product sales (Barone, Norman, \& Miyazaki, 2007; Fritz, 2011). According to a 2008 study by Cone, $85 \%$ of respondents had a positive attitude toward a product/service when the company who owned the product/service helped a charity by donating part of the sales to that charity. In addition, almost $80 \%$ of respondents said that if the quality of the product and the price were similar, they would be more likely to switch their purchase to the brand that was associated with helping a charity ("Consumer Behavior Study," 2008). Various past studies have examined the effects of cause-related marketing practices and found that consumers' favorable attitudes toward the brands and their companies have increased and have led to an increase in product evaluation and purchase intentions (Brown \& Dacin, 1997; Cui, Trent, Sullivan, \& Matiru, 2003; Gupta \& Pirsch, 2006; Nan \& Heo, 2007; Ross, Patterson, \& Stutts, 1992; Webb \& Mohr, 1998; van den Brink, Odekerken-Schröder, \& Pauwels, 2006). This leads to the development of the following hypothesis.

H1: The level of purchase intention for products with CSR involvement will be higher than those with no CSR involvement

\subsubsection{Brand Naming}

A suitable and good brand name is one of the most influential forces in marketing. It is one of the major forces that drive consumer decision making to purchase the product. Brand names can be used to infer to product image, the perceived origin of the product, and the quality of the product. Thus, the name of the brand is related to the concept of product country image (PCI), a widely studied concept during the past two decades. The brand naming also coincides with the concept of country of origin (COO) effect. The concept of product country image and the concept of country of origin are deemed to have an influential effect on product evaluation and consumer decision making process. Products perceived to be owned by corporations from different countries may be perceived differently from one another. Some countries may be renowned for some types of product categories (Baker \& Ballington, 2002). For example, Japanese home electronics and digital devices are generally perceived and evaluated differently from Mexican or Indian or Chinese products. Italy is one of the countries in the world that is renowned for her leatherwear and other leather goods. The same can also be said for German cars and Japanese cars. Recently, South Korea has also been accepted as a country that is renowned for her home electronics and digital devices.

Product country image can be conceptualized as consumers' overall perception of the quality of the product made in a particular country (Crawford \& Garland, 1988; Dagger \& Raciti, 2011; Han \& Terpstra, 1989). Similarly, Bilkey and Nes (1982) refers to product country image as the belief about a product from a country on a set of product attributes, such as reliability, performance, design, features, quality, and the like. Consumers' 
beliefs tend to be different across different product categories from different countries (Bilkey \& Nes, 1982; Kaynak \& Cavusgil, 1983). Kotler, Haider, and Rein (1993, p.141) refer to country image as "the sum of beliefs and impressions people hold about places." Li, Fu, and Murray (1997, p.166) refer to country image as "consumers' images of different countries and of products made in these countries." Country image and product image are two separate but related concepts. Product image from a particular country may be affected by the image of that country.

The relationship between country image and product image has become a topic of great interest in the area of country of origin concept for a long time (Agarwal \& Sikri, 1996; Dagger \& Raciti, 2011). Country of origin may be referred to as the manufacturing country or the assembly country (Lin \& Chen, 2006; White, 1979) or the country of the headquarters of the company that owns the product (Cavusgil \& Ozsomer, 1991; Douglas, Johansson, \& Nonaka, 1985; Saeed, 1994). Chasin and Jaffe (1979), Chattalas, Kramer, and Takada (2008), as well as Nagashima (1977) used the word "made in..." to refer to the country that manufactures the product. In today's complex manufacturing environment, the most influential aspect tends to rest on the country of the company that owns the brand or the product. For example, Toyota is owned by a Japanese company, whose headquarters is located in Japan but some models of the cars may be manufactured in Thailand, Indonesia, or other countries. In addition, the components or parts that are used to manufacture Toyota's cars may come from other countries. If this were the case, how would consumers evaluate the brand or the product? Which cue has the most influential effect on product evaluation by consumers? In general, the most influential element that drives consumer decision making process is deemed to be based on the country of the company who owns the brand. For instance, if we see a SONY's electronic device, we will generally perceive its product to be a good quality product because the brand SONY conveys the idea that it is owned by a Japanese firm renowned for producing electronic devices. Hence, the name of the brand is considered to be a crucial element driving the inner perception of consumers. In this research, we will specifically use the term country of origin to refer to the country of the company that owns the brand or the product. It is believed that consumers will evaluate and judge the brand by the country that owns the brand. Country of manufacturing or country of assembly will have less influence on consumer decision making process. Thus, the country of origin in this sense can be used as an extrinsic cue for product evaluation (Chattalas et al., 2008).

A product's country of origin or product country image (PCI) tends to have an influential effect on consumer evaluation of the product. Past research has shown that country image has an impact on consumers' product evaluation (Han \& Terpstra, 1988; Josiassen \& Assaf, 2010; Lin \& Chen, 2006; Roth \& Romeo, 1992; Tse \& Gorn, 1993). A product/brand that comes from a country with good image and is renowned for that product will have a competitive advantage over other products/brands competing in the same market (Lin \& Chen, 2006; Prendergast, Tsang, \& Chan, 2010; Verlegh \& Steenkamp, 1999). In a particular market, a product/brand perceived to be from a country reputed for manufacturing that product is more likely to be recognized and preferred than those products/brands owned by local companies (Yamoah, 2005). This implies that the brand name itself will have an effect on consumer decision making. The name of the brand that conveys the image that the product/brand is from a renowned country for manufacturing that type of product will be likely to be adopted even though the product/brand itself may be locally produced. In general, the majority of consumers may not know the country of origin of the product/brand (Samiee, Shimp, \& Sharma 2005). For example, Chinese consumers were not able to distinguish foreign brands from local brands. The survey on the perceptions of 67 brand names among Chinese consumers indicated that all consumers could not tell the country of origin that owned the brand names correctly. In addition, the results also showed that $75 \%$ of consumers wrongly perceived the country that owned the brand "Jasonwood," a Chinese brand name owned by a Chinese company. They believed that the brand "Jasonwood" was owned by a foreign company (Zhuang, Wang, Zhou, \& Zhou, 2008). Past research also indicates that consumers in a developing country tend to prefer brands owned by foreign companies much more than brands that are locally made and owned by local companies (Zhuang et al., 2008). Hence, it is not surprising to find those technological products and some other consumer products owned by Thai companies (local companies) adopt the brand names that convey the idea that the brands are owned by those foreign companies renowned for manufacturing those products. This leads to the following hypothesis.

H2: The level of purchase intention for products with foreign brand name will be higher than those with Thai brand name.

\subsubsection{Pricing}

Price is defined as "the amount of money we must sacrifice to acquire something we desire" (Monroe, 1990, p. 5). Price is considered a core component of value and is one of the 4Ps in marketing mix strategies. It is the only component in the 4Ps that generates revenue. All other components are costs related (Diamantopoulos, 2003; 
Rao \& Kartono, 2009). Pricing is deemed to be an influential factor in determining consumers' purchase intentions. Pricing is the way to determine what a company will receive in exchange for its offerings, i.e., tangible goods or intangible services. Pricing factors consist of costs of goods/service sold, administrative expenses, advertising and promotion expenses, competition in the market, economic situation, and the perceived quality of the product (Kotler \& Keller, 2006; Pricing, 2012). The principles for determining prices have fundamentally been based on cost-oriented, competition-oriented, or demand-oriented pricing (Cravens \& Piercy, 2009; Kotler \& Keller, 2006).

In the era of borderless and free trade competition, corporations competing in the marketplace must render great efforts to build and sustain competitive advantage if they wish to survive, succeed, and grow (Hamel \& Prahalad, 1993; Ma, 1999; Minoja, Zollo, \& Coda, 2010; Porter, 1985, 2008). In this situation, the market offerings must consist of reasonable price, good quality, and good services (Aaker, 1992; Kotler \& Keller, 2006). It appears that pricing is a major component driving firms to gain competitive advantage. In principle, price is deemed to have an effect on consumer decision making process (Cram, 2008; Gijsbrechts, 1993; Lichtenstein \& Burton, 1989; Rao \& Monroe, 1989). Price may be perceived to be an indicator of quality. The price quality relationship appears to be correlated (Tellis \& Wernerfelt, 1987). The higher the price, the higher the perceived quality (Cram, 2008; Gijsbrechts, 1993; Rao \& Monroe, 1989). Tellis and Wernerfelt (1987) developed a model of the equilibrium price quality relationship in a free market entry with asymmetrically informed consumers and showed that the price quality relationship is generally increasing with the level of information consumers received (Gijsbrechts, 1993). In addition, price may be perceived to be an indicator of monetary sacrifice, i.e., the ability to pay. This means that when consumers evaluate products, they have to trade off their monetary sacrifice with the offerings. If they perceive the offerings to be of good value, i.e., being worthwhile for the money they have to pay, they will be willing to buy those offerings (Cram, 2008; Monroe, 1990; Monroe \& Krishnan, 1985; Zeithaml, 1988).

In today's market, companies' competitive edge mostly depends on pricing. In most cases, price represents the amount of money consumers have to pay to exchange for the offerings they wish to acquire. Generally, consumers are sensitive to the amount of money they have to pay. This is referred to as price sensitivity. Price sensitivity can be defined as the awareness of consumers concerning what they perceive to be the cost of a particular product or service they wish to buy (Diamantopoulos, 2003). If the price is perceived to be too high, consumers may be reluctant and hesitate to buy. In contrast, if the price is perceived to be reasonable and have good value, consumers will be willing to pay for those offerings (Miller, 2012). Customers for all product and service categories have some level of price sensitivity. A small change in price may have a significant effect on the firm's revenue. It is imperative that marketers must try to understand the price sensitivity of their target customers and understand how much change is perceived to be an acceptable level (Goldsmith, Flynn, \& Kim, 2010).

The concept of price sensitivity is based on the economic theory and its analysis of price elasticity. It is a percentage change in quantity units as a result of a percentage change in price (Diamantopoulos, 2003). Price sensitivity was first examined by Gabor and Granger (1966). They conducted a study to determine upper and lower price limits for some inexpensive products. The result of their study suggested that the range between the upper and lower price limits did not hinder consumers' intention to purchase but these limits had an effect on quantity purchase instead. The concept of price limits was further developed into price sensitivity meter (PSM) by van Westendorp (1976). The PSM was basically a method for determining consumer price preferences and has been adopted and used by marketers for several decades (Van Westendorp's Price Sensitivity Meter, 2012). Travers (1983) expanded the model by investigating the degree of consumer price resistance over a range of prices associated with the perception of quality. Based on the concept of price sensitivity, it can be concluded that if the actual price goes above the upper limit, consumers will not be willing to pay for the product. In contrast, if the actual price drops below the lower limit, consumers will be more willing to spend money to purchase the product and, perhaps, to purchase the product in greater quantity. Thus, for a high involvement and technological product, it is believed that the level of prices will have an effect on consumers' purchase intention. This leads to the following hypothesis.

\section{H3: The level of purchase intention for products with high prices will be lower than those with low prices.}

\subsection{Two Way Interaction Effect between CSR Involvement and Brand Naming}

The effect of CSR involvement on consumers' purchase intentions may also depend on the perception of the origin of the product/brand. The effects may be different between products using a Thai brand name and those using a foreign brand name (i.e., signifying that the product is from a country that has an expertise in 
manufacturing that product). For the Thai brand name (i.e., local brand name), consumers tend to be more supportive and more sympathetic toward the brand if the brand is involved in a cause-related marketing campaign, a form of CSR. They believe that doing good deeds such as donating money to a charitable organization will result in good things; hence, their level of purchase intentions toward the brand will be more likely to increase. On the other hand, if the product/brand is perceived to be from a country renowned for manufacturing that product, the product/brand itself will generally be more preferable by local consumers than the local brand (Josiassen \& Assaf, 2009). Brand image will become a major criterion in their purchase evaluation. Whether or not the product/brand is involved in a cause-related marketing campaign will have no influential effect on consumers' purchase intentions since the brand itself is perceived to be of high quality with good image. CSR involvement will be less likely to have a significant effect on consumers' purchase intentions. This leads to the following hypothesis.

H4: The effect of CSR involvement on purchase intention will be stronger for products with Thai brand name than those with foreign brand name.

\subsection{Two Way Interaction Effect between CSR Involvement and Pricing}

The effect of CSR involvement on consumers' purchase intentions may also depend on the perceived price of the product/brand. The effects may be different between products selling at a lower price and those selling at a higher price. Based on the price sensitivity concept, products with lower prices will generally be more acceptable and preferable by consumers and, as a result, the level of their purchase intentions tends to be higher than those products with higher prices (Diamantopoulos, 2003). Their main purchase criterion is likely to be based on the price itself. Consumers are likely to accept lower price products with acceptable quality level. In this sense, a CSR involvement campaign will have little effect on consumers' purchase intentions since the product/brand itself is perceived to have good value. On the other hand, consumers will be reluctant and somewhat hesitate to purchase the product/brand if the product/brand itself has a higher price. Consumers will use several purchase criteria for their product evaluation. The main purchase criterion is likely to be based on brand image. In this sense, a cause-related marketing campaign will likely have an influential effect on consumers' purchase intentions since a CSR involvement campaign will likely help enhance the brand image. Hence, the following hypothesis is derived.

H5: The effect of CSR involvement on purchase intention will be stronger for products with higher prices than those with lower prices.

\subsection{Two Way Interaction Effect between Pricing and Brand Naming}

The effect of pricing on consumers' purchase intentions may also rest on the perception of the origin of the product/brand. The effects may be different between products using a Thai brand name and those using a foreign brand name (i.e., signifying that the product is from a country that has an expertise in manufacturing that product). In general, products with a foreign brand name are likely to be more acceptable and preferable than products with a Thai brand name (Chattalas et al., 2008). For the Thai brand name (i.e., local brand name), consumers' purchase criteria tend to be based on price as a major factor for their product evaluation. If the price is lower than the reference price limit, consumers will be more likely to provide greater support and adopt the product (Cram, 2008). In contrast, if the price is higher than the reference price limit, consumers will be less likely to purchase the product. Consumers tend to believe that a local brand name with a higher price will be less likely to provide them with good value. In this case, the effect of pricing on consumers' purchase intentions will be strong. On the other hand, Thai consumers, in general, will prefer to buy a product with foreign brand names. If the price of the product is lower than the reference price limit, consumers will not hesitate to adopt the product. If the price of the product is higher than the reference price limit, some consumers may consider switching to purchase a different brand name. However, because of the product/brand image that signifies the quality of the product, some consumers may still have positive evaluation toward the product and do not hesitate to purchase the product. In this situation, the effect of pricing on consumers' purchase intentions will be somewhat weaker. This leads to the following hypothesis.

H6: The effect of pricing on purchase intention will be stronger for products with Thai brand name than those with foreign brand name.

\subsection{Three Way Interaction Effect among CSR Involvement, Brand Naming, and Pricing}

In the case of products with higher prices, the effect of CSR involvement on consumers' purchase intentions is likely to depend on the perception of the origin of the product/brand. The effects will be different between products using a Thai brand name and those using a foreign brand name (Chattalas et al., 2008; Josiassen \& 
Assaf, 2009). For the Thai brand name (i.e., local brand name), only a small number of consumers will be willing to support and purchase the product/brand. With the high price, most consumers will perceive the local product/brand to be less valuable. Hence, CSR involvement will be less likely to have any significant effect on consumers' purchase intentions toward the local brand. On the other hand, Thai consumers, in general, will be more likely to prefer foreign products/brands. Their main purchase criterion will significantly be based on brand image since it is believed that owning a product with good brand image will help enhance their personal image. As a result, consumers' purchase intentions in this case will be higher than those of local brand name. In this situation, when the foreign product/brand is involved in a cause-related marketing campaign, a form of CSR, the result will be the multiplier effect of CSR involvement on consumers' purchase intentions. This may be the result of the belief in a Buddhism concept of karma that doing good deeds such as donating money to help a charitable organization or society or education will provide them with good fortune and outcomes. In contrast, for the products with lower prices, the effect of CSR involvement on consumers' purchase intentions is likely to be no difference between products using a Thai brand name and those using a foreign brand name. In this case, Thai consumers will be more likely to use price as a major purchase criterion to evaluate the product. Price will become the most influential determinant of consumer decision making process. Other purchase criteria will be less likely to have any significant effect on consumers' purchase intentions. In this situation, CSR involvement will have no influential effect on consumers' purchase intentions. Thus, the following hypothesis is derived.

H7: In the case of products with higher prices, the effect of CSR involvement on purchase intention will be stronger for products with foreign brand name than those with Thai brand name. In contrast, in the case of products with lower prices, CSR involvement will have no effect on purchase intention regardless of the products' brand names.

\section{Research Methodology}

This research was based on causal research using a $2 \times 2 \times 2$ experimental design. The purpose was to test the main and interaction effects of CSR involvement, brand naming, and pricing on consumers' purchase intentions. A computer notebook was selected as a high involvement and technological product for the experiment. Donating part of the revenue from the selling of the product to help the poor was adopted as a cause-related marketing campaign, a form of CSR. A hypothetical brand name was adopted for the study. Toshisu was used to represent a foreign brand name that signifies that the product was owned by a Japanese corporation and Siam Computer was adopted as a brand name to represent a local brand manufactured by a local corporation. The price of 29000 Baht was used to represent a high price and the price of 14900 Baht was used to represent a low price. Third and fourth year students (i.e., juniors and seniors) from a local university were recruited and used as experimental subjects. These students were mature and had good responsibility. They were also in need of using a computer notebook for their studies. In addition, these students had purchasing power to buy the computer notebook adopted for the experiment. The study contained eight experimental conditions as shown in Table 1.

Table 1. Experimental conditions

\begin{tabular}{cccc}
\hline Experimental Condition & CSR Involvement & Brand Naming & Pricing \\
\hline 1 & Having CSR Involvement & Toshisu & High \\
2 & Having CSR Involvement & Toshisu & Low \\
3 & Having CSR Involvement & Siam Computer & High \\
4 & Having CSR Involvement & Siam Computer & Low \\
5 & No CSR Involvement & Toshisu & High \\
6 & No CSR Involvement & Toshisu & Low \\
7 & No CSR Involvement & Siam Computer & High \\
8 & No CSR Involvement & Siam Computer & Low \\
\hline
\end{tabular}

The sample size for each experimental condition was 50 students. The total sample size for all the eight conditions was 400 students. Students were randomly assigned to each experimental condition. Eight versions of the questionnaire were developed for the experiment. Each version of the questionnaire was used for each experimental condition. The questionnaire contained two sections. The first section dealt with questions regarding consumers' purchase intentions. First, subjects were told that they were in the process of making a decision to buy a computer notebook for personal use and had come across an advertisement in a magazine 
indicating a newly advanced computer notebook with a particular brand (i.e., Toshisu brand or Siam Computer brand) and a particular price (i.e., high price or low price). In addition, the advertisement for the condition of having CSR involvement also contained the statement saying that part of the revenue from selling the product would be donated to help the poor. There would be no donation statement for the experimental conditions that had no CSR involvement. Second, subjects were asked about their purchase intentions toward that computer notebook by indicating their level of purchase intentions on a 7 point scale ranging from "very unlikely" to "very likely." Finally, questions regarding manipulation check were also asked. Subjects were asked about which country they believed the computer notebook in the advertisement was from (Thailand or Japan or another country). Subjects were also asked if the price of the computer notebook was high or low and if the statement of the advertisement contained information about donating part of the revenue from selling the product to help the poor. The second section of the questionnaire contained questions about the subjects' demographic information. After the subjects had completed the questionnaires, they were informed of the purpose of the study and the experimental factors they had encountered.

Data from the 400 completed questionnaires were then coded using 1 and 0 . The code for the experimental conditions of having CSR involvement, using a foreign brand name, and selling at a high price was 1 and the code for having no CSR involvement, using a Thai brand name, and selling at a low price was 0 .

\section{Analysis and Results}

\subsection{Sample Characteristics}

Descriptive statistics regarding the sample characteristics were computed. The sample consisted of $43.75 \%$ male and $56.25 \%$ female. The mean age was 21.85 with a standard deviation of 1.22 . The minimum age was 20 and the maximum age was $26.10 .2 \%$ of students had monthly income below 5000 Baht. $60.6 \%$ of students had monthly income between 5000 - 9999 Baht. 16.5\% of students had monthly income between $10000-14999$ Baht. $12.7 \%$ of students had monthly income of 15000 Baht and above.

\subsection{Manipulation Check}

The results of the manipulation check indicated that $100 \%$ of subjects believed that Toshisu was a computer notebook from Japan. Concerning Siam Computer notebook, $98.75 \%$ believed that it was a brand made locally and owned by a Thai corporation. Only $1.25 \%$ of subjects suspected that the brand might be from another country. For pricing, $100 \%$ of subjects believed that the price of 29000 Baht was a high price and the price of 14 900 Baht was a low price. For the advertisement indicating CSR involvement, $100 \%$ of subjects said that they saw the information about "part of the revenue from selling the product to help the poor." For the advertisement that contained no information about donation, all subjects indicated that no such donation activity was inferred to in the advertisement. The manipulation check suggested that all the subjects understood very well about the three factors used in the experiment, i.e., foreign brand name VS Thai brand name, high price VS low price, and having CSR involvement VS no CSR involvement.

\subsection{Hypothesis Testing}

A $2 \times 2 \times 2$ completely randomized factorial design was used in the experiment. Minitab was used to test the main and interaction effects of CSR involvement, brand naming, and pricing. The results of the analysis were presented in Table 2.

Table 2. Main and interaction effects of CSR involvement, brand naming, and pricing on consumers' purchase intentions

\begin{tabular}{lccccl}
\hline \multicolumn{1}{c}{ Variable } & DF & SS & MS & F & p-value \\
\hline CSR Involvement & 1 & 6.25 & 6.25 & 12.65 & $0.000^{* * *}$ \\
Brand Naming & 1 & 29.16 & 29.16 & 59.03 & $0.000^{* * *}$ \\
Pricing & 1 & 125.44 & 125.44 & 253.94 & $0.000^{* * *}$ \\
CSR Involvement x Brand Naming & 1 & 2.56 & 2.56 & 5.18 & $0.023^{*}$ \\
CSR Involvement x Pricing & 1 & 3.24 & 3.24 & 6.56 & $0.011^{*}$ \\
Pricing x Brand Naming & 1 & 8.41 & 8.41 & 17.02 & $0.000^{* * *}$ \\
CSR Involvement x Brand Naming x Pricing & 1 & 3.61 & 3.61 & 7.31 & $0.007^{* *}$ \\
\hline
\end{tabular}

Note: $\mathrm{R}^{2}=47.99 \%$; ** Significant at $0.001 ; * *$ Significant at $0.01 ; *$ Significant at 0.05 
The test results in Table 2 indicated that the three main effects of CSR involvement, brand naming, and pricing were statistically significant at a 0.001 level. The graphic representations of the three main effects were presented in Figures $1-3$.

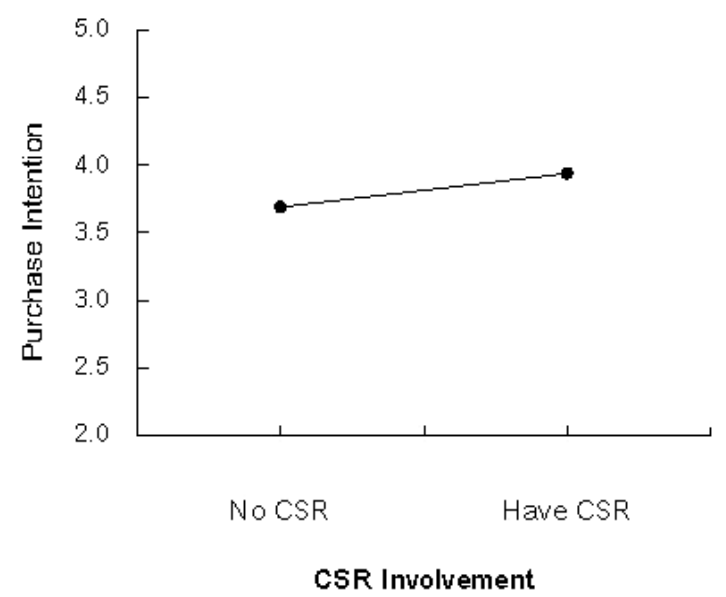

Figure 1. The main effect of CSR involvement on purchase intention

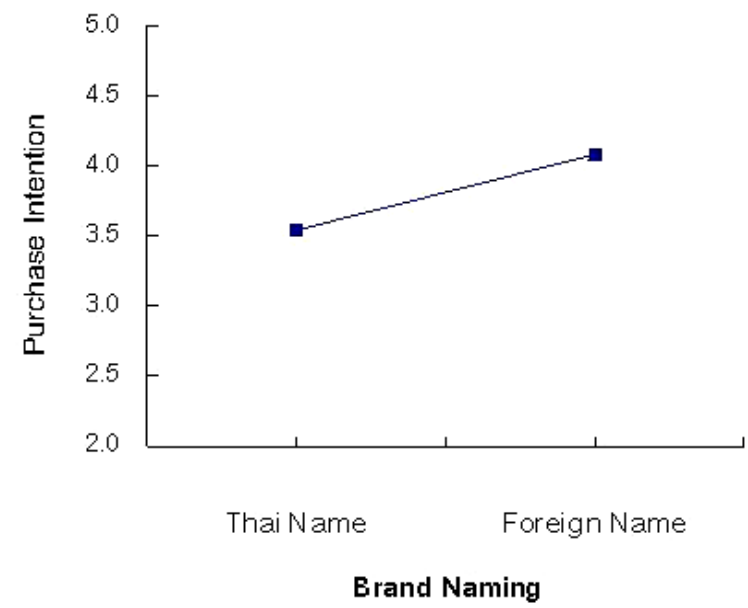

Figure 2. The main effect of brand naming on purchase intention

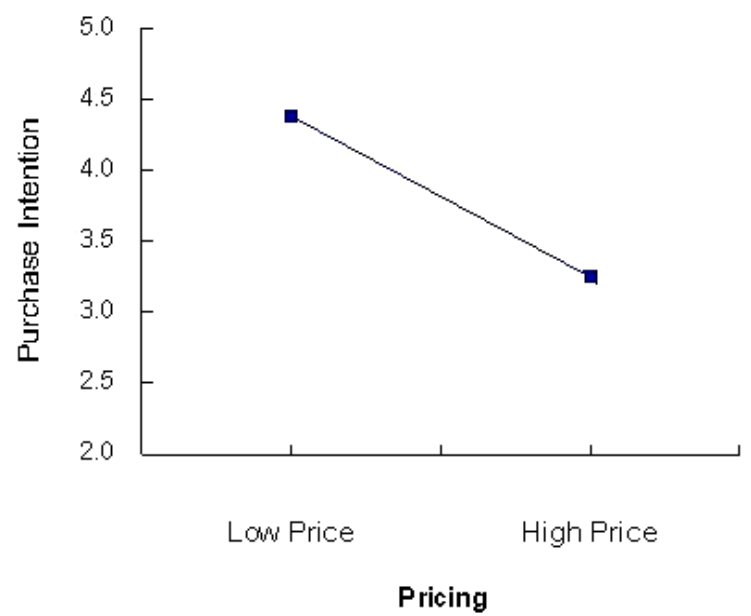

Figure 3. The main effect of pricing on purchase intention 
Figure 1 indicated that the level of purchase intention for products with CSR involvement was higher than those with no CSR involvement. Along the same line, Figure 2 also suggested that the level of purchase intention for products with foreign brand name was higher than those with Thai brand name. On the other hand, Figure 3 showed that the level of purchase intention for products with high prices was lower than those with low prices. Therefore, $\mathrm{H} 1, \mathrm{H} 2$, and $\mathrm{H} 3$ are supported.

Table 2 also suggested that the two way interaction effect between CSR involvement and brand naming was statistically significant at a 0.05 level and the graphic representation of this interaction effect was shown in Figure 4.

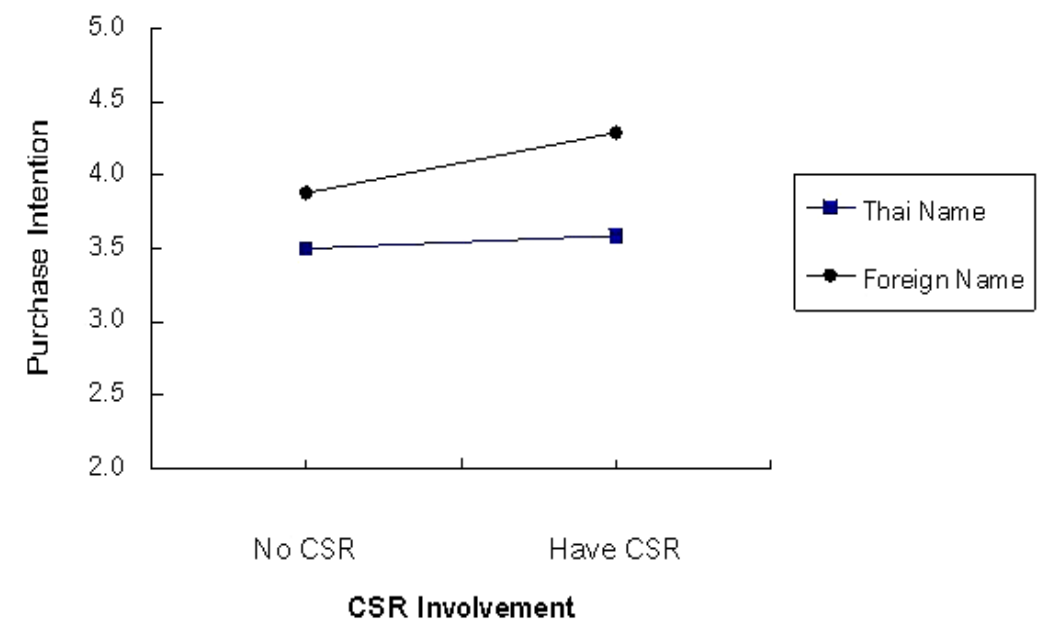

Figure 4. Two way interaction effect between CSR involvement and brand naming

Hypothesis 4 stated that the effect of CSR involvement on purchase intention would be stronger for products with Thai brand name than those with foreign brand name. The graphic representation in Figure 4 indicated that when a Thai brand name was used, CSR involvement had little effect on purchase intention. However, when a foreign brand name was adopted, CSR involvement had a stronger effect on purchase intention. This suggests that $\mathrm{H} 4$ is not supported. Even though $\mathrm{H} 4$ was found to be statistically significant, the direction of the interaction effect was different from what was expected.

The results from Table 2 showed that the two way interaction effect between CSR involvement and pricing was statistically significant at a 0.05 level. The graphic representation of this interaction effect was derived and presented in Figure 5.

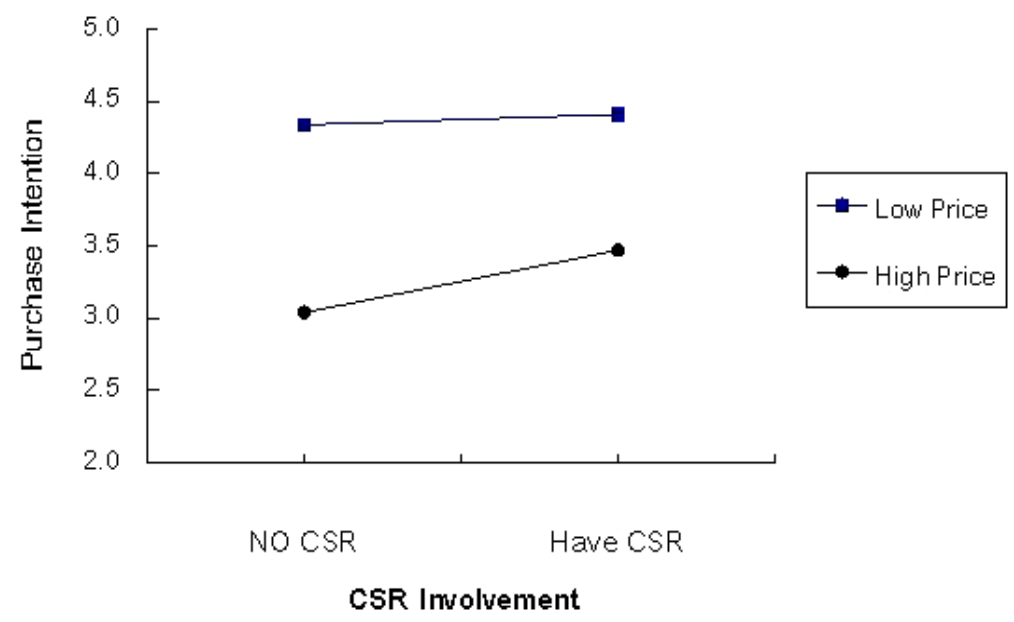

Figure 5. Two way interaction effect between CSR involvement and pricing 
The graphic representation shown in Figure 5 suggested that consumers, in general, preferred products with lower prices than those with higher prices and the effect of CSR involvement on purchase intention was stronger for products with higher prices than those with lower prices. This result was consistent with hypothesis 5 . Therefore, H5 is supported.

Based on the result in Table 2, it was found that the interaction effect between pricing and brand naming was statistically significant at a 0.001 level. Then, a graphic representation to present this interaction effect was derived. The graphic representation was presented in Figure 6.

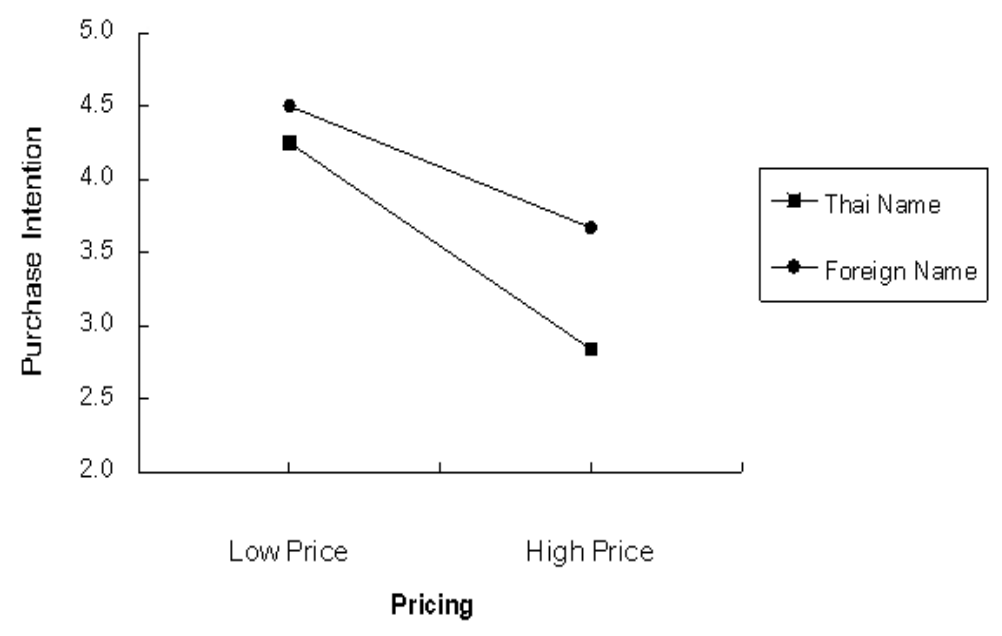

Figure 6. Two way interaction effect between pricing and brand naming

Hypothesis 6 stated that the effect of pricing on purchase intention would be stronger for products with Thai brand name than those with foreign brand name. The graphic representation of this interaction effect shown in Figure 6 was consistent with the hypothesis. Therefore, H6 is supported.

The result of the three way interaction effect among CSR involvement, brand naming, and pricing shown in Table 2 indicated that this three way interaction effect was statistically significant at a 0.01 level. The graphic representation of this three way interaction was then derived and presented in Figure 7.

High Price Condition

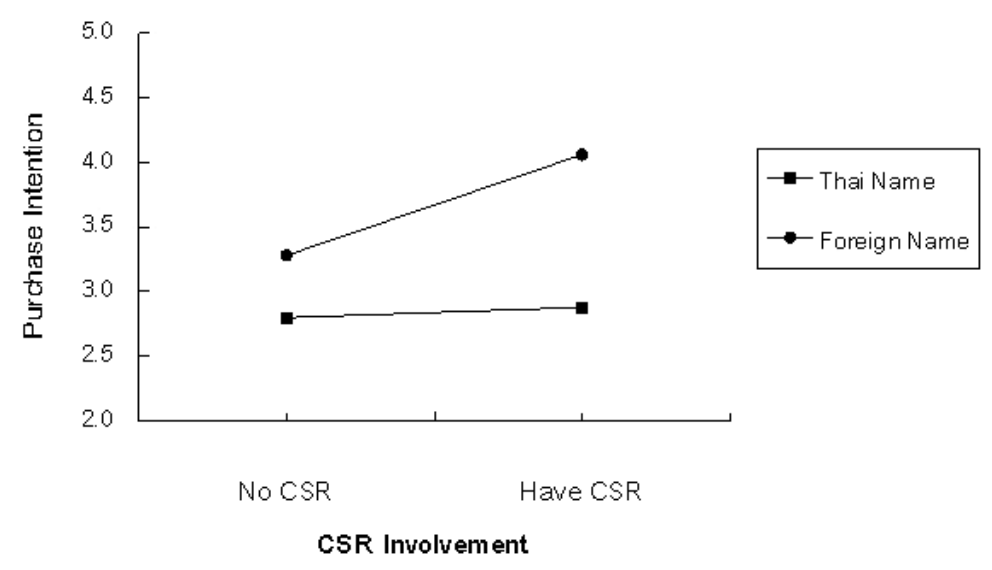


Low Price Condition

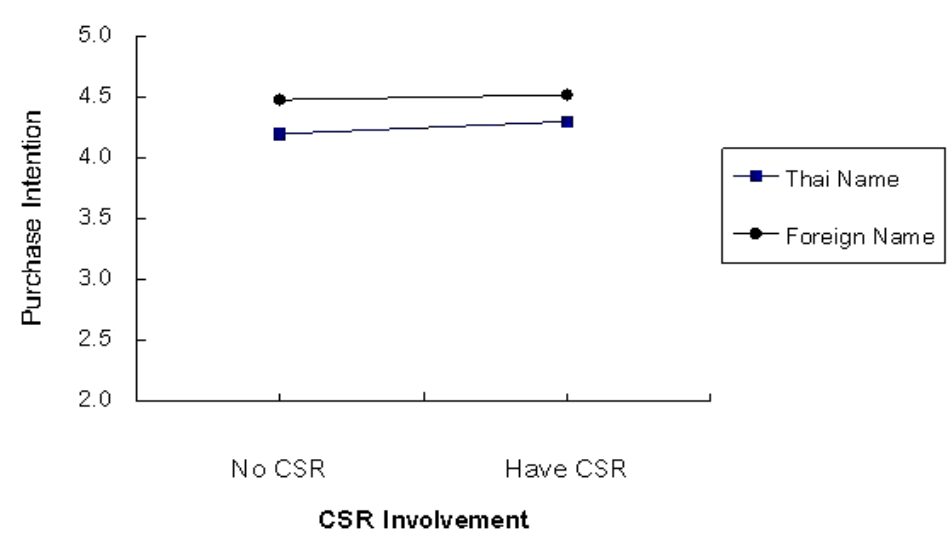

Figure 7. Three way interaction effect among CSR involvement, brand naming, and pricing

Hypothesis 7 suggested that in the case of products with higher prices, the effect of CSR involvement on purchase intention would be stronger for products with foreign brand name than those with Thai brand name. In contrast, in the case of products with lower prices, CSR involvement would have no effect on purchase intention regardless of the products' brand names. The graphic representation shown in Figure 7 was found to be consistent with what was expected in hypothesis 7. Therefore, $\mathrm{H7}$ is supported.

\section{Discussion and Implication}

Our experiment showed that all of our experimental factors consisting of CSR involvement, brand naming, and pricing had an effect on consumers' purchase intentions. It was found that consumers' purchase intention for products with CSR involvement was higher than those with no CSR involvement. This indicates that linking the product/brand with a good CSR campaign will help enhance brand image and, as a result, will have a positive effect on consumer decision making process. All firms, regardless of their sizes, can help the community and the society by carrying out a CSR campaign. Even though this study focuses on a cause-related marketing campaign, any other type of CSR campaigns can also be utilized to help enhance corporate image and brand image. Similarly, the level of consumers' purchase intention for products with foreign brand name was found to be higher than those with Thai brand name. This suggests that the name of the brand is a sensitive issue and may have an effect on the product image. Hence, local firms must pay close attention to the brand name of a high involvement and technological product. Adopting a Thai brand name will not help in this regard. Local firms must try to adopt a brand name that signifies that the brand is owned by a corporation from a country that has an expertise in manufacturing that product. A past example supports this result. Tanin, a Thai brand name for radios and televisions, emerged in the market about 30 years ago. The company expected Thai consumers to be patriotic and buy the locally made products. However, the brand was later out of business due to several reasons and one key reason was that Thai consumers preferred Japanese brands more than a Thai brand. In addition, Thai consumers believed that a Thai brand owned by a Thai corporation would not have a technological capability to manufacture technological products; hence, a Thai electrical appliance was believed to have lower quality than a Japanese brand (Thai Electrical Appliances Tanin, 2012). For pricing, it was evident that the level of consumers' purchase intentions for products with high prices was found to be lower than those with low prices. The result was consistent with the concept of price sensitivity (Diamantopoulos, 2003). Consumers, in general, tend to prefer products with lower prices; hence, given the acceptable level of quality, pricing the product/brand at a lower price level will help stimulate consumer decision making process. Consumers will hesitate to buy the product/brand if the product/brand has a high price. Even though a higher price product may signify the higher level of quality, consumers will still hesitate to buy the product. The result suggests that an acceptable quality level with a lower/inexpensive price will help stimulate consumers' decision making process.

The result of the two way interaction effect between CSR involvement and brand naming suggests that a good brand strategy is to use a foreign brand name to signify that the product is from a renowned country since implementing a CSR campaign on a foreign brand name will help enhance consumers' purchase intentions. Implementing a CSR campaign on a local brand name will have little effect on consumers' decision making process. The two way interaction effect between CSR involvement and pricing also suggests that implementing a 
CSR campaign will have a positive effect on consumers' purchase intentions toward products with higher prices but have little effect on products with lower prices. This means that for products with higher prices, one of the purchase criteria consumers use for product evaluation is a CSR involvement campaign of the product. The two way interaction effect between pricing and brand naming suggests that consumers tend to prefer foreign brand names more than local/Thai brand names. The effect of pricing on consumers' purchase intentions will be stronger for products with local/Thai brand names than those with foreign brand names. The above two way interaction results imply that consumers tend to prefer products with foreign brand names and lower prices. Implementing a CSR campaign will only have a positive effect on products with foreign brand names and on products with higher prices.

The result of the three way interaction effect provides a clear understanding of the relationships among the three experimental factors. In the case of products with higher prices, it is evident that the effect of CSR involvement on consumers' purchase intentions is stronger for products with foreign brand names than those with Thai brand names. It also appears that for products with higher prices consumers tend to prefer foreign brand names much more than Thai brand names. When examining the case of products with lower prices, the result shows that consumers still prefer foreign brand names more than Thai brand names but implementing a CSR campaign does not have any effect on consumers' decision making process. The implication of this is consistent with the results from the two way interaction effects. Implementing a CSR campaign will only have a positive effect on foreign brand names with higher prices. Thus, when launching a new technological product, corporations must consider using a foreign brand name to signify that the brand is associated with a country that has an expertise in manufacturing that product. In this situation, implementing a CSR campaign will work if the product is a premium product with higher prices. If the price of the product is at an acceptable/low level, CSR involvement will have very little effect on consumers' purchase intentions. In this case, it is recommended that the corporation should implement a CSR campaign to enhance the overall corporate image rather than the brand image. Moreover, adopting a local/Thai brand name will only work if the price is low and the target consumers are those with limited income level.

\section{Contribution of the Study}

The contribution of this study is on the investigation of both main and interaction effects of CSR involvement, brand naming, and pricing by using an experimental design that contains a high level of internal validity. The main effects provide clearer evidence and a better understanding of the positive effects of CSR involvement and brand naming on consumers' purchase intentions. The study also provides additional evidence that supports the concept of price sensitivity, i.e., consumers prefer products with lower prices more than products with higher prices. Additional contribution of this study is on the two way and three way interaction effects of the three experimental factors. Very limited research in the past has investigated the interaction effects among CSR involvement, brand naming, and pricing. The concept of CSR and the concept of product country image or country of origin were extended and the results have enlightened our understanding of the concepts. The concept of country of origin has been extended to cover the issue of brand naming (regardless of the country of the corporation that owns the product). It is evident from the results of the study that implementing a CSR campaign will work effectively on products with foreign brand names and on products with higher prices.

\section{Limitations and Future Research}

One limitation was that this study was based on an experimental design using students as subjects. In addition, the study focused on one form of CSR, i.e., a cause-related marketing campaign. Future research may want to carry out a survey research to investigate the main and interaction effects of CSR involvement, brand naming, and pricing and see whether the results from survey research are consistent with the results from the experiment carried out in this study. Another interesting area of future research is to compare the effects of several forms of CSR campaigns on corporate image and brand image and examine whether corporate image and brand image have any significant effect on consumers' decision making process. As Kotler and Lee (2005) point out that there are six forms of CSR, i.e., cause promotions, cause-related marketing, corporate social marketing, corporate philanthropy, community volunteering, and socially responsible business practices. The brand naming concept may also be extended to investigate the effect of brand naming on other high involvement product categories.

\section{Conclusion}

This study was carried out to investigate the main and interaction effects of CSR involvement, brand naming, and pricing by using an experimental design. A $2 \times 2 \times 2$ completely randomized factorial design was carried out to test the effects of the three experimental factors. Eight versions of the questionnaire were developed for the study. Each version was designed to match each of the eight experimental conditions $(2 \times 2 \times 2=8)$. A 
cause-related marketing campaign by donating part of the revenue from selling the product to help the poor was used as a form of CSR involvement. A computer notebook was selected as a high involvement and technological product with a hypothetical brand name. Toshisu was used to represent a foreign brand name signifying that the brand is owned by a corporation from Japan, a renowned country for manufacturing technological products whereas Siam Computer was used to represent a local/Thai brand name manufactured by a Thai corporation. A high price and a low price were used to represent the pricing factor. Students from a local university were recruited and used as subjects for the experiment. Fifty students were randomly assigned to each of the eight experimental conditions. The total number of students used as subjects was 400 . The results suggested that all the experimental factors had significant effects on consumers' purchase intentions. The levels of purchase intentions were higher for products with CSR involvement, for products using foreign brand names, and for products with lower prices. The two way and three way interaction effects suggested that implementing a CSR campaign only worked for products adopting foreign brand names and using higher prices. CSR involvement would have little effect on products with lower prices and products using local/Thai brand names. The contribution of this study is on the investigation of both main and interaction effects of CSR involvement, brand naming, and pricing by using an experimental design that contains a high level of internal validity.

\section{References}

Aaker, D. (1992). Strategic management (3rd ed.). New York, NY: John Wiley \& Sons.

Agarwal, S., \& Sikri, S. (1996). Country image: Consumer evaluation of product category extensions. International Marketing Review, 13(4), 23-39. http://dx.doi.org/10.1108/02651339610127239

Arslan, F. M., \& Altuna, O. K. (2010). The effect of brand extensions on product brand image. Journal of Product \& Brand Management, 19(3), 170-180. http://dx.doi.org/10.1108/10610421011046157

Baker, M. J., \& Ballington, L. (2002). Country of origin as a source of competitive advantage. Journal of Strategic Marketing, 10(2), 157-168. http://dx.doi.org/10.1080/09652540210125297

Barone, M. J., Norman, A. T., \& Miyazaki, A. D. (2007). Consumer response to retailer use of cause-related marketing: Is more fit better? Journal of Retailing, 83, 437-445. http://dx.doi.org/10.1016/j.jretai.2007.03.006

Berglind, M., \& Nakata, C. (2005). Cause-related marketing: More buck than bang? Business Horizons, 48, 443-453. http://dx.doi.org/10.1016/j.bushor.2005.04.008

Bilkey, W. J., \& Nes, E. (1982). Country-of-origin effects on product evaluations. Journal of International Business Studies, 13(1), 89-99. http://dx.doi.org/10.1057/palgrave.jibs.8490539

Brown, T. J., \& Dacin, P. (1997). The Company and the Product: Corporate Associations and Consumer Product Responses. Journal of Marketing, 61(1), 68-84. http://dx.doi.org/10.2307/1252190

Carroll, A. B. (1979). A three-dimensional conceptual model of corporate performance. Academy of Management Review, 4, 497-505.

Cause Marketing. (2012). From Wikipedia, the free encyclopedia. Retrieved from http://en.wikipedia.org/wiki/Cause_marketing

Cause-Related Marketing. (2012). Marketing Examples. Retrieved from http://uwmktg301.blogspot.com/2010/01/cause-related-marketing.html

Cause-Related Marketing: Why Social Change and Corporate Profits Don't Mix (2012). PR Watch. Retrieved from http://www.prwatch.org/node/4965

Cavusgil, S., \& Ozsomer, A. (1991). Country-of-origin effects on product evaluations: A sequel to Bilkey \& Nes review. In Gilly et al (Eds.), AMA Educators Proceedings (pp. 269-277). Chicago.

Chasin, J., \& Jaffe, E. (1979). Industrial buyer attitudes toward goods made in eastern Europe. Columbia Journal of World Business, 14, 74-81.

Chattalas, M., Kramer, T., \& Takada, H. (2008). The impact of national stereotypes on the country of origin effect: A conceptual framework. International Marketing Review, 25(1), 54-74. http://dx.doi.org/10.1108/02651330810851881

Chen, C. H. (2011). The major components of corporate social responsibility. Journal of Global Responsibility, 2(1), 85-99. http://dx.doi.org/10.1108/20412561111128546 
Consumer Behavior Study Confirms Cause-Related Marketing Can Exponentially Increase Sales. (2008, October 1). Business wire. Retrieved from http://www.businesswire.com/news/home/20081001005317/en/Consumer-Behavior-Study-Confirms-Cause -Related-Marketing-Exponentially

Corporate Social Responsibility. (2012). From Wikipedia, the free encyclopedia. Retrieved from http://en.wikipedia.org/wiki/Corporate_social_responsibility

Corporate Social Responsibility: a new definition, a new agenda for action. (2012). Europa, Press Release RAPID. Retrieved from http://europa.eu/rapid/pressReleasesAction.do?reference=MEMO/11/730\&format=HTML\&aged=0\&langua $\mathrm{ge}=\mathrm{EN} \&$ guiLanguage $=\mathrm{en}$

Cram, T. (2008). Pricing. In M. J. Baker and S. Hart (Eds.), The marketing book (pp. 281-295). Burlington, MA: Butterworth-Heinemann. http://dx.doi.org/10.1016/B978-0-7506-8566-5.50018-2

Cravens, D. W., \& Piercy, N. F. (2009). Strategic marketing (9th ed.). Burr Ridge, IL: Irwin/McGraw-Hill.

Crawford, J. C., \& Garland, B. C. (1988). German and American perceptions of product quality. Journal of International Consumer Marketing, 1(1), 63-78. http://dx.doi.org/10.1300/J046v01n01_04

Cui, Y., Trent, E. S., Sullivan, P. M., \& Matiru, G. N. (2003). Cause-related marketing: How generation Y responds. International Journal of Retail \& Distribution Management, 31, 310-320. http://dx.doi.org/ $10.1108 / 09590550310476012$

Dagger, T. S., \& Raciti, M. M. (2011). Matching consumers' country and product image perceptions: An Australian perspective. Journal of Consumer Marketing, 28(3), 200-210. http://dx.doi.org/10.1108/07363761111127626

Davis, F. D., Bagozzi, R. P., \& Warshaw, P. R. (1992). Extrinsic and intrinsic motivation to use computers in the

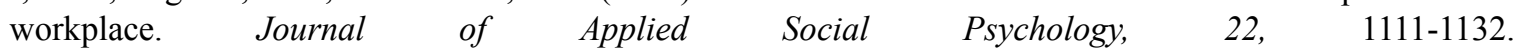
http://dx.doi.org/10.1111/j.1559-1816.1992.tb00945.x

Diamantopoulos, A. (2003). Pricing. In M. J. Baker (Ed.), The marketing book (pp. 342-359). Burlington, MA: Butterworth-Heinemann.

Donaldson, T., \& Preston, L. E. (1995). The stakeholder theory of the corporation: concepts, evidence, and implications. The Academy of Management Review, 20(1), 65-91.

Douglas, S. P., Johansson, J. K., \& Nonaka, I. (1985). Assessing the impact of country of origin of product evaluations: A new methodological perspective. Journal of Marketing Research, 22, 388-396. http://dx.doi.org/10.2307/3151584

Fritz, J. (2011). Cause-related marketing: What you need to know. Retrieved from http://nonprofit.about.com/od/fundraising/a/causemarketing.htm

Gabor, A., \& Granger, C. W. J. (1966). Price as an indicator of quality: Report on an inquiry. Economica, 33, 43-70. http://dx.doi.org/10.2307/2552272

Galbreath, J. (2009). Building corporate social responsibility into strategy. European Business Review, 21(2), 109-127. http://dx.doi.org/10.1108/09555340910940123

Gardberg, N. A., \& Fombrun, C. (2006). Corporate citizenship: Creating intangible assets across institutional $\begin{array}{llll}\text { environments. Academy of } & \text { Management }\end{array}$ http://dx.doi.org/10.5465/AMR.2006.20208684

Gijsbrechts, E. (1993). Prices and pricing research in consumer marketing: Some recent developments.

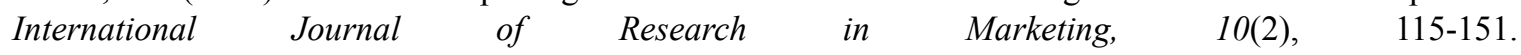
http://dx.doi.org/10.1016/0167-8116(93)90001-F

Goldsmith, R. E., Flynn, L. R., \& Kim, D. (2010). Status consumption and price sensitivity. Journal of Marketing Theory and Practice, 18, 323-338. http://dx.doi.org/10.2753/MTP1069-6679180402

Gupta, S., \& Pirsch, J. (2006). The company-cause-customer fit decision in cause-related marketing. Journal of Consumer Marketing, 23, 314-326. http://dx.doi.org/10.1108/07363760610701850

Hamel, G., \& Prahalad, K. C. (1993). Strategy as stretch and leverage. Harvard Business Review, 71(2), 75-84.

Han, C. M., \& Terpstra, V. (1988). Country of origin effects for uni-national and bi-national Products. Journal of International Business Studies, 19(2), 235-255. http://dx.doi.org/10.1057/palgrave.jibs.8490379 
Josiassen, A., \& Assaf, A. (2010). Country-of-origin contingencies: Their joint influence on consumer behaviour. Asia Pacific Journal of Marketing and Logistics, 22(3), 294-313. http://dx.doi.org/10.1108/13555851011062241

Kaynak, E., \& Cavusgil, S. T. (1983). Consumer attitudes toward products of foreign origin: Do they vary across product classes? International Journal of Advertising, 2, 147-157.

Keller, K. L. (1993). Conceptualizing, measuring, and managing customer-based brand equity. Journal of Marketing, 57(1), 1-22. http://dx.doi.org/10.2307/1252054

Kotler, P., \& Keller, K. L. (2006). Marketing management (12th ed.). Upper Saddle River, NJ: Prentice Hall.

Kotler, P., \& Lee, N. (2005). Corporate social responsibility: Doing the most good for your company and your cause. Hoboken, NJ: John Wiley \& Sons, Inc.

Kotler, P., Haider, D. H., \& Rein, I. J. (1993) Marketing places: Attracting investment, industry, and tourism to cities, states, and nations. New York: The Free Press.

Lee, H. M., Lee, C. C., \& Wu, C. C. (2011). Brand image strategy affects brand equity after M\&A. European Journal of Marketing, 45, 1091-1111. http://dx.doi.org/10.1108/03090561111137624

Li, Z. G., Fu, S., \& Murray, W. L. (1997). Country and product images: The Perceptions of consumers in the People's Republic of China. Journal of International Consumer Marketing, 10(1-2), 115-138. http://dx.doi.org/10.1300/J046v10n01_07

Lichtenstein, D., \& Burton, S. (1989). The relationship between perceived and objective price-quality. Journal of Marketing Research, 26, 429-443. http://dx.doi.org/10.2307/3172763

Lin, L. Y., \& Chen, C. S. (2006). The influence of the country-of-origin image, product knowledge and product involvement on consumer purchase decisions: an empirical study of insurance and catering services in Taiwan. Journal of Consumer Marketing, 23(5), 248-265. http://dx.doi.org/10.1108/07363760610681655

Ma, H. (1999). Creation and preemption for competitive advantage. Management Decision, 37(3), 259-267. http://dx.doi.org/10.1108/00251749910264497

Matten, A., \& Crane, D. (2005). Corporate citizenship: Toward an extended theoretical Conceptualization. Academy of Management Review, 30, 166-179. http://dx.doi.org/10.5465/AMR.2005.15281448

McClary, R. V. (2006). An evaluation of consumer buying criteria and its impact on the purchase of commoditized laptops. Unpublished doctoral dissertation. Capella University.

Meehan, J., Meehan, K., \& Richards, A. (2006). Corporate social responsibility: The 3C-SR model. International Journal of Social Economics, 33, 386-398. http://dx.doi.org/10.1108/03068290610660661

Miller, L. (2012). Understanding price sensitivity in marketing. Retrieved from http://voices.yahoo.com/understanding-price-sensitivity-marketing-13994.html

Minoja, M., Zollo, M., \& Coda, V. (2010). Stakeholder cohesion, innovation, and competitive advantage. Corporate Governance, 10(4), 395-405. http://dx.doi.org/10.1108/14720701011069632

Mistine. (2012). Retrieved from http://thaicatwalk.com/wordpress/?p=3659

Mitsubishi Electric. (2012). Retrieved from http://www.mitsubishi-kyw.co.th/start/

Moir, L. (2001). What do we mean by corporate social responsibility? Corporate Governance, 1(2), 16-22. http://dx.doi.org/10.1108/EUM0000000005486

Monroe, K. B. (1990). Pricing: Making profitable decisions (2nd ed.). New York, NY: McGraw Hill.

Monroe, K. B., \& Krishnan, R. (1985). The effect of price on subjective product evaluations. In J. Jacoby and J. Olsen (Eds), Perceived quality: How consumers view stores and merchandise (pp.209-232). Lexington, MA: Lexington Books.

Nagashima, A. (1977). A Comparative 'made in' product image survey among Japanese businessmen. Journal of Marketing, 6(1), 95-100. http://dx.doi.org/10.2307/1250943

Nan, X., \& Heo, K. (2007). Consumer response to corporate social responsibility (CSR) initiatives. Journal of Advertising, 36(2), 63-74. http://dx.doi.org/10.2753/JOA0091-3367360204

Phillips, R. (2003). Stakeholder theory and organizational ethics. San Francisco, CA: Berrett-Koehler Publishers, Inc. 
Porter, M. E. (1985). Competitive advantage: Creating and sustaining superior performance. New York, NY: The Free Press.

Porter, M. E. (2008). The five competitive forces that shape strategy. Harvard Business Review, 86(1), 79-93.

Prendergast, G. P., Tsang, A. S. L., \& Chan, C. N. W. (2010). The interactive influence of country of origin of brand and product involvement on purchase intention. Journal of Consumer Marketing, 27(2), 180-188. http://dx.doi.org/10.1108/07363761011027277

Pricing. (2012). From Wikipedia, the free encyclopedia. Retrieved from http://en.wikipedia.org/wiki/Pricing

Rao, V. R., \& Kartono, B. (2009). Pricing objectives and strategies: A cross-country survey. In V. R. Rao (Ed.), Handbook of pricing research in marketing (pp. 9-36). Northampton, MA: Edward Elgar Publishing Limited.

Rao, V. R., \& Monroe, K. B. (1989). The effect of price, brand name and store name on buyers' perceptions of product quality: An integrative review. Journal of Marketing Research, 26, 351-357. http://dx.doi.org/10.2307/3172907

Ross, J. K., Patterson, L. T., \& Stutts, M. A. (1992). Consumer perceptions of organizations that use cause-related marketing. Journal of the Academy of Marketing Science, 20(1), 93-97. http://dx.doi.org/10.1007/BF02723480

Roth, M. S., \& Romeo, J. B. (1992). Matching product category and country image perceptions: A framework for managing country-of-origin effects. Journal of International Business Studies, 23, 477-498. http://dx.doi.org/10.1057/palgrave.jibs. 8490276

Saeed, S. (1994). Consumer evaluation of products in a global market. Journal of International Business Studies, 25, 579-604. http://dx.doi.org/10.1057/palgrave.jibs.8490213

Samiee, S., Shimp, T. A., \& Sharma, S. (2005). Brand origin recognition accuracy: Its antecedents and consumers' cognitive limitations. Journal of International Business Studies, 36, 379-397. http://dx.doi.org/10.1057/palgrave.jibs. 8400145

Social News. (2012). Deedeenews. Retrieved from http://www.deedeenews.com/category/society/

Sundar, S. (2012). Cause-related marketing: Tactic or strategy? Retrieved from http://www.scribd.com/doc/5079207/Cause-related-marketing-PG

Tellis, G., \& Wernerfelt, B. (1987). Competitive price and quality under asymmetric information. Marketing Science, 6(3), 240-253. http://dx.doi.org/10.1287/mksc.6.3.240

Ten Best Notebook (2012). Retrieved from http://www.nextag.com/10-best-notebook/shop-html

Thai Electrical Appliances Tanin (2012). Retrieved from http://atcloud.com/stories/63981

Top Eight Cause-Related Marketing Campaigns of 2007. (2008, January 1). Cause Marketing. Retrieved from http://causerelatedmarketing.blogspot.com/2008/01/top-eight-cause-related-marketing.html

Top Three Best Reviews (2012). Retrieved from http://www.consumersearch.com/washing-machine-reviews

Travers, K. (1983). PSM: A new technique for determining consumer sensitivity to pricing. Los Angeles, CA: Plog research

Tse, D. K., \& Gorn, G. J. (1993). An experiment on the salience of country-of-origin in the era of global brands. Journal of International Marketing, 1(1), 57-76.

Van den Brink, D., Odekerken-Schröder, G., \& Pauwels, P. (2006). The effect of strategic and tactical cause-related marketing on consumers' brand loyalty. Journal of Consumer Marketing, 23(1), 15-25.

Van Westendorp, P. (1976). NSS-price sensitivity meter (PSM) - A new approach to study consumer perception of price. Proceedings of the 29th ESOMAR Congress, Venice, 5-9 September 1976, 139-167.

Van Westendorp's Price Sensitivity Meter (2012). From Wikipedia, the free encyclopedia. Retrieved from http://en.wikipedia.org/wiki/Van_Westendorp's_Price_Sensitivity_Meter

Varadarajan, P. R., \& Menon, A. (1988). Cause-related marketing: A co-alignment of marketing strategy and corporate philanthropy. Journal of Marketing, 52(3), 58-74. http://dx.doi.org/10.2307/1251450

Verlegh, P., \& Steenkamp, J. B. (1999). A review and meta analysis of country-of-origin research. Journal of Economic Psychology, 20, 521-546. http://dx.doi.org/10.1016/S0167-4870(99)00023-9 
Webb, D. J., \& Mohr, L. A. (1998). A Typology of consumer responses to cause-related marketing: From skeptics to socially concerned. Journal of Public Policy \& Marketing, 17, 226-238.

White, P. D. (1979). Attitudes of US purchasing managers towards industrial products manufactured in selected European nations. Journal of International Business Studies, 10, 81-90. http://dx.doi.org/10.1057/palgrave.jibs. 8490632

Windsor, D. (2001). Corporate citizenship: Evolution and interpretation. In J. Andriof, \& M. McIntosh (Eds.), Perspectives in Corporate Citizenship (pp. 39-52). Sheffield, UK: Greenleaf.

Wood, D. J. (1991). Corporate social performance revisited. Academy of Management Review, 16, 691-718.

Yamoah, F. A. (2005). Role and impact of product-country image on rice marketing: A developing country perspective. The Journal of American Academy of Business, 7, 265-276.

Zeithaml, V. (1988). Consumer perceptions of price, quality and value: A means-end model and synthesis of evidence. Journal of Marketing, 52(3), 2-22. http://dx.doi.org/10.2307/1251446

Zhuang, G., Wang, X., Zhou, L., \& Zhou, N. (2008). Asymmetric effects of brand origin confusion: Evidence from the emerging market of China. International Marketing Review, 25, 441-457. http://dx.doi.org/10.1108/02651330810887486 